\title{
Students' Difficulties in Answering the Written Expression Section of the TOEFL Test at English Study Program of State Islamic University of SUSKA Riau
}

\author{
Mainar Fitri \\ Faculty of Education and Teacher Training, \\ State Islamic University of Sultan Syarif Kasim Riau, \\ Pekanbaru, Riau, Indonesia \\ mainar@uin-suska.ac.id
}

\begin{abstract}
TOEFL test is one of the requirements for the students of English Study Program of State Islamic University of Sultan Syarif Kasim Riau (UIN Suska Riau) to finish their study at $S 1$ Degree. Based on the researcher's observation, most of the students did not pass the TOEFL Test. The students followed the test for several times till they reached the passing grade. It seemed that the students got difficulties in answering the TOEFL Test. So, in this research the researcher focused on analyzing the students' difficulties in answering the Written Expression section of the TOEFL test. The aims of this research were to identify the categories of items in the Written Expression section of the TOEFL test which were difficult for the fourth semester students of English Study Program UIN Suska Riau, and to identify which categories of items that were easy for the students. This research was a quantitative research. The researcher analyzed the categories of items tested in TOEFL test, especially in the Written Expression section. There were 12 categories of items tested in the Written Expression section of the TOEFL test based on Longman Preparation Course for the TOEFL Test by Deborah Phillips (2000: 144-221). The categories consisted of subject-verb agreement, parallel structure, comparative and superlative, the use of the verbs, the forms of the verbs, passive verbs, nouns, pronouns, adjectives and adverbs, articles, prepositions and usages The result of the research showed that all of the categories of items were difficult for the students. None of the categories of items were easy for the students. The most difficult category for the students was usages. So, in general, the students extremely got difficulties in answering the Written Expression section of the TOEFL test.
\end{abstract}

Keywords: Analyzing the Difficulties, Written Expression of TOEFL Test.

\section{INTRODUCTION}

TOEFL stands for test of English as a foreign language. It is probably the most often used examination in the admission process of foreign students to college and universities in the United States (Michael; 1995:4). Sharpe (2000:
9) states that since 1963 the TOEFL has been used by Latin American Scholarship program and others as a standard of measurement of English proficiency. Now, some professional licensing and certification agencies also use TOEFL score to fulfill the foreign language requirement for doctoral 
candidates whose first language is not English. There are three sections of the TOEFL test. They are Listening Comprehension section, Structure and Written Expression Section and Reading Comprehension Section. Listening Comprehension section measures the ability to understand conversation and talks in English. The Structure and Written section measures the ability to recognize language that is appropriate for standard written English. Reading Comprehension section measures the ability to read and understand short passages.

TOEFL test is one of the requirements for all students of Islamic State University of Sultan Syarif Kasim Riau Pekanbaru to finish their study. The students can register to follow the Munaqasah exam (thesis exam) if they have passed the TOEFL test. If they cannot reach the minimal standard of passing grade, they must retake the test till they can reach the minimal standard of passing grade. Especially in English Department of Education and Teacher Training Faculty, the students can pass the TOEFL test if they can reach the minimal score above 450. In English Study Program, the students have to take the TOEFL test which is usually used in comprehensive test as a requirement to complete their SI degree. They are provided with courses that can help them increase their TOEFL scores. They have listening comprehension, grammar and reading comprehension subjects. Those can help them in answering the TOEFL test.

In this research, the researcher focused her study on analyzing the difficulties faced by the fourth semester students of English Study Program UIN Suska Riau Pekanbaru in answering the Written Expression section of the TOEFL test. The difficulties faced by the students in answering the written expression of the TOEFL test referred to the categories of items of the Written Expression section of the TOEFL test that the students answered incorrectly. There were 12 categories of items tested in the Written Expression section of the TOEFL test according to Deborah Philips in her book entitled "Longman Preparation Course for the TOEFL test (2000: 144 - 221). The categories consisted of subject/-verb agreement, parallel structure, comparative and superlative, the form of the verb, the use of the verb, passive sentences, verbs, nouns, pronouns, adjectives, adverbs, articles, preposition and usages.

The researcher had two reasons to do this research. Firstly, the fourth semester students of English Study Program of UIN Suska Riau have learned Grammar subjects that gave them contributions in answering the Written Expression section of the TOEFL test. They learned Grammar for 3 semester, starting from Basic English Grammar, Intermediate English Grammar and Advanced English Grammar. However, the students may get difficulties in answering the Written Expression section of the TOEFL test because the items of the Written Expression questions of the TOEFL test can be a little tricky (Phillips, 2000 : 144). For example; the item of subjectverb agreement. Sometimes prepositional phrases can come between a subject and a verb. If the object of the preposition is singular and the subject is plural, or if the object of the preposition is plural and the subject is singular, there can be confusion in making the subject and the verb agree, e.g. The key to the doors are in the drawer. The students may consider that the sentence is correct because they think that the main subject is the key to the doors, the doors is the word which is closer to the verb are. The doors is plural so that they may think that 
the verb must be in the plural form. The correct form of the sentence above is The Key to the doors is in the drawer, because the main subject of the sentence is the key, which is singular, so that it needs the singular verb "is". Secondly, they may get difficulties in answering the Written Expression section of the TOEFL test because of the interference of their first language. As Brown (1993: 193) states that the main cause of learners' difficulties and mistakes in learning the target language is the interference from their first language into the target language. In this case, the Written Expression section of the TOEFL test examines the students' knowledge to express themselves in the correct way in English writing. While there is a different way to express themselves in writing between their first language; Indonesian and the target language; English. For example, a student expresses a noun phrase, in Indonesian " teman-teman baru ". When he or she expresses it in English, she or he may express" friend new" while the correct one is new friends. It probably occurs as a result of the interference from his or her first language, Indonesian, into English. Based on the example above, it can be concluded that there is a different way to express the noun phrase between English and Indonesian. In Indonesian, the modifier comes after the modified word while in English, the modifier comes before the modified word.

The purpose of this research was to identify which categories of items of the Written Expression section of the TOEFL test that were difficult for the students. By identifying the difficult categories faced by the students in answering the Written Expression section of the TOEFL test, it can give contributions for students, who want to follow the test. The students can pay attention to the categories of the Written
Expression section of the TOEFL test, especially for the categories that are considered difficult in order to prepare themselves in the comprehensive exam on usage as one of the requirements to finish their study at S1 Degree. Other contributions are for lecturers. Lecturers can teach the structure and grammar subjects clearly that give contribution to the students in answering the Written Expression section of the TOEFL test and lecturers can explain the strategies of answering the Written Expression section of the TOEFL test.

\section{LITERATURE REVIEW}

\section{a. The Written Expression Section of the TOEFL Test}

The Written Expression section of the TOEFL test examines the people's knowledge of the correct way to express themselves in English writing (Phillips: 143). In the Written Expression section of the TOEFL test, the people who take the TOEFL test are asked to identify an error in sentences by choosing one of the four underlined words or phrases that must be changed in order for the sentences to be correct.

Deborah Phillips in her book entitled "Longman Preparation Course for the TOEFL test (2000: 144 - 221) describes skills that help participants in answering the Written Expression section of the TOEFL test. She classifies the skills based on the problems that appear in answering the Written Expression questions. The problems are subject/ verb- agreement, parallel structure, comparative and superlative, the form of the verb, the use of the verb, passive sentences, verbs, nouns, pronouns, adjectives, adverbs, articles, preposition and usages. 


\section{b. Subject-Verb Agreement}

Subject /verb agreement is simple. If the subject of a sentence is singular, then the verb must be singular. If the subject of the sentence is plural, the verb must be plural. An -s on a verb shows that the verb is singular while an $\mathrm{s}$ on a noun shows that the noun is plural. But do not forget about the irregular plurals of nouns such as women, children, people, etc.

There are some situations on the TOEFL test when subject-verb agreement can be a little tricky. The situations are when the positions of subject-verb agreement appear after prepositional phrases, expressions of quantity, inverted verbs, certain words. So, the skills that the people, who take the test, should master when dealing with subject-verb agreement in answering the Written Expression section of the TOEFL test are:

1) Make verbs agree after prepositional phrases.

Sometimes prepositional phrases can come between the subject and the verb. If the object of the preposition is singular and the subject is plural, or of the object of the preposition is plural and the subject is singular, there can be confusion in making the subject and verb agree. For example;

The key to the doors is in the drawer. The keys to the door are in the drawers.

In the example (a) you might think that doors is the subject because it comes directly in front of the be verb. So, you might think that are is the correct form of the be verb in a plural form because the subject is plural (doors) However, doors is not the subject because it is the object of the preposition to. The subject of the sentence is key, so the verb must be is. In the example (b), it is the same case with example (a), The main subject of the sentence (b) is keys not the door. So, the subject "keys "agrees with the verb are because the subject is in a plural form

2) Make verbs agree after expressions of quantity.

A particular agreement problem occurs when the subject is an expression of quantity such as all, most, or some, followed by the preposition of. In this situation, the subject (all, some, most) can be singular or plural, depending on what follows the preposition of. For example;

All of the book was interesting. All of the books were interesting All of the information was interesting

In the first example, the subject All refers to the singular noun book, so the correct verb is therefore the singular verb was. In the second example, the subject All refers to the plural noun books, so the correct verb is the plural verb were. In the third example, the subject $A l l$ refers to the uncountable noun information, so the correct verb is therefore the singular verb was.

3) Make inverted verbs Agree There are some situations in which the subject comes after the verb. The situations occur after question words, after place expressions, after negative expressions, after omitted conditional, and after some comparisons. When the subject and verb are inverted, it can be difficult to locate them, and it can 
therefore be a problem to make them agree. For example:

Behind the house were the bicycles I wanted.

Behind the house was the bicycle I wanted.

In the examples above, behind the house is not the subject of sentences but an object of preposition behind. The subject in the example (1) is bicycles. The subject comes after the verb because of the place expression behind the house. Because the subject bicycles is plural, the verb must be changed to the plural were. While in the example (2) the subject is bicycle, which is in singular form, so verb must be was in singular form too.

4) Make verbs agree after certain words

Certain words in English are always grammatically singular, even though they may have plural meanings. For example: everybody is going to the theater. Even though we understand from the example that a lot of people are going to the theatre, everybody is singular and requires a singular verb is going. The certain words which are singular but have a plural meaning consist of: everybody, everyone, everything, nobody, somebody, nobody, nothing, etc.

\section{c. Parallel Structures}

In good English, an attempt should be made to make the language as even and balanced as possible. This balance is called parallel structure. The parallel structure can be achieved by making the forms of words as similar as possible. For example: I like singing and dancing or I like to sing or to dance. Both sentences are parallel structure because they have similar forms "singing and dancing" both are gerunds while "to sing and to dance" both are "to infinitives".

There are several situations in which participants of the TOEFL test should be particularly careful of parallel structure. Parallel structures are required in the following situations. (1). with coordinate conjunctions, such as and, but and or. (2). With paired conjunction, such as both....and, either...or, neither...nor, not only... but also. (3). So, the skills they have to master related to this problem are:

1. Use Parallel structure with coordinate conjunction.

The job of coordinate conjunction (and, but, or) is to join together equal expressions. In other words, what is on one side of these words must be parallel in what is on the other side. These conjunctions can join nouns, or verbs, or adjectives, or phrases, or subordinate clauses or main clauses; they just must join together two of the same thing. For example;

(a). He eats and sleeps only when he takes a vacation. (two verbs are joined by coordinate conjunction)

(b.) My boss is sincere and nice. (two adjectives are joined by coordinate conjunction)

(c). There are students in the classroom and in front of the building. (two phrases are joined by coordinate conjunction)

(d). I am here because I have to be and because I want to be. (two clauses are joined by coordinate conjunction) 
2. Use Parallel structure with Paired Conjunctions.

The paired conjunctions both.......and, either.... or, neither.... nor, not only.... but also, require parallel structure. For example;

(a). I know both where you went and what you did.

(b). Either Mark or Sue has the book.

(c). The tickets are neither in my pockets nor in my purse.

(d). He is not only an excellent student but also an outstanding athlete.

3. Use Parallel Structure with comparisons.

When a sentence is comparative. It describes the similarities and the differences between the two things. The similarities or the differences must be in parallel form. The comparative sentences are indicated by $-e r . .$. than or the more... than. e.g. My school is farther than your school. What is written is more easily understood than what is spoken. A comparison showing how two things are the same might contain as... as or expression such as the same as or similar to. For example; Their car is as big as a small house. Renting those apartments costs about the same as leasing them. The work that I did is similar to the work that you did.

\section{d. Comparatives and Superlatives}

Sentences with incorrect comparatives and superlatives can appear on the TOEFL test. It is therefore important to know how to do the following.

1. Form comparatives and superlatives correctly.

The problem with some of the comparative and superlative sentences on the TOEFL test is that the comparative or superlative is formed incorrectly. So, it is important to understand how to form the comparative and superlative to answer such question correctly.

The comparative is formed with either -er or more and than. In the comparative, -er is used with short adjectives such as tall, and more is used with longer adjectives such as beautiful. For examples; Bob is taller than Ron. Sally is more beautiful than Sharon.

The superlative is formed with the, either -est or most, and sometimes in, of, or a thatclause. In the superlative, -est is used with short adjectives such as tall, and most is used with longer adjectives such as beautiful. For examples ; Bob is the tallest man in the room. Sally is the most beautiful of all the women at the party. The spider over there is the largest one that I have ever seen. The fastest runner wins the race. (no in, of, or that)

2. Use comparatives and superlatives correctly.

Another problem with the comparatives and superlatives on the TOEFL test is that they can be used incorrectly. The comparatives and superlatives have different uses, and it is important to understand the different uses to answer such questions correctly. For example; the history class is the largest in the school. Mary is more intelligent than Sue. 
In the first example, the history class is being compared with the math class. In the second examples Mary is being compared with Sue. The superlative is used when there are more than two items to compare and you want to show the one that is the best, the biggest, or in some way the most outstanding.

3. Use the irregular -er, er structure correctly.

An irregular comparative structure that has been appearing frequently on the TOEFL test consist of two parallel comparatives introduced by the. For the example; the harder he tried, the further he fell behind. The two parallel comparatives in this sentence is harder and further.

In this type of sentence, the and the comparison can be followed by a number of different stuctures. For examples; The more children you have, the bigger the house you need; the harder you work, the more you accomplish; the greater the experiences, the higher the salary. In the first examples, the more is the followed by the noun children and the subject and verb you have, while the bigger is the followed by the noun the house and the subject and verb you need. In the second examples, the harder is followed by the subject and verb you work, while the more is followed by the subject and verb you accomplish. In the third examples, the grater is followed only by the noun the experience, while the higher is followed only by the noun the salary. You should note that this last example does not even contain a verb, yet it is a correct structure in English.

\section{e. The Forms of the Verb}

It is common in the Written Expression part of the TOEFL test for the verbs to be formed incorrectly. Therefore, the forms of the verb should be checked correctly. The forms of the verb consist of the base form, the present tense, the present participle, and the past participle. The strategies that the participants have in answering Written Expression of the TOEFL test related to the forms of the verb are: firstly, check what comes after have. If the form of the verb appearing after have is the base form and present participle except past participle, so, it is wrong, because the form of the verb after have is the past participle e.g. the students have taken the test.

Secondly, check what comes after be. It is correct if the present participle or the past participle come after be; e.g. the students are taking the test. Thirdly, check what comes after will, would and other modal auxiliaries. The form of the verb after will, would and other modals is the base form; e.g. He will leave at $08.00 \mathrm{pm}$ next week.

\section{$f$. The Uses of the Verb}

Many different problems in using the correct verb tense are possible in English. However, four specific problems occur frequently on the TOEFL test. So, it is important to 
pay attention to these four as skills needed in answering the Written Expression of the TOEFL test.

1. Knowing when to use the past with the present.

One verb tense problem that is common both in students' writing and in the TOEFL test is the switch from the past tense to present for no particular reason. Often when a sentence has both a past tense and a present tense, the sentence is incorrect. E.g. He took the money when he wants it. This sentence says that he took the money (in the past) when he wants it. (in the present). This sentence can be corrected in several ways, depending on the desired meaning. He took the money when he wanted it (in the past). The meaning of this sentence is logical and the sentence is correct. He takes the money when he wants it (habitually) also has a logical meaning and the sentence is correct.

It is necessary to point out, however, that it is possible for a logical sentence in English to have both the past and the present tense. The error needed to avoid is the switch from the past to the present for no particular reason. Therefore, when you see a sentence on the TOEFL test with both the past and the present tense, you must check the meaning of the sentence carefully to see if it is logical in English.

2. Using had and have correctly.

Two tenses that are often confused are the present perfect and the past perfect. Both tenses have completely different uses and you must understand how to differentiate them. The present perfect (have+ past participle) refers to the period of time from the past until the present; e.g. Sue has lived in Los Angeles for ten years. The past perfect tense (had + past participle) refers to a period of time that started in the past and ended in the past, before something else happened in the past; e.g. Sue had lived in Los Angeles for ten years when she moved to San Diego

3. Using the correct tense with expression.

Often in sentences in the Written Expression section of the TOEFL test there is a time expression that clearly indicates what verb tense is needed in the sentence; e.g. We moved to New York in 1970. The time expression in this sentence is in 1970 indicating the time expression of simple past.

So, the verb must be in simple past "moved". Each tense is characterized by time expressions. For example: simple present uses time expression such as everyday/year/night to show a habitual action. Simple past uses ago, last week/year/night, etc. Present progressive uses right now as a time expression.

4. Using the correct tense with will and would. 
Certain combination of verb are very common in English. One is the combination of the simple present and will.

I know that they will arrive soon.

It is certain that he will graduate.

Another combination that is quite common is

Another combination that is quite common is the combination of the simple past and would.

I knew that the would arrive.

It was certain that the would graduate.

It is important to stress that in the combination discussed here, the present should be used with will and the past should be used with would; the generally should not be mixed. The common errors that must generally be avoided are the combination of the past with will and the combination of the present with would.

I know that he would* arrive soon.

It was certain that he will* graduate.

In the first examples, the present, know, is illogical with would. It can be corrected in two different ways.

I knew that he would arrive soon.

I know that he will arrive soon.

In the second examples, the past, was, is illogical with will. It can also be corrected in two different ways.

It was certain that he would graduate.

It is certain that he will graduate.

\section{g. Passive Verb}

Sentences in which the error is an incorrect passive are common in the Written Expression of the TOEFL test. To answer the question of the Written Expression of the TOEFL test related to passive verb correctly, it is important to be able to recognize correct form of the passive and to determine when a passive verb rather than an active verb is needed in a sentence.

The difference between an active and passive verb is that the subject in an active sentence does the action of the verb, and the subject in a passive sentence receives the action of the verb. To convert a sentence from active to passive, two changes must be made. (1) the subject of the active sentence becomes the object of the passive sentence, while the object of the active sentence becomes the subject of the passive sentence. (2) the verb in the passive sentence is formed by putting the helping verb be in the same form as the verb in the active sentence and the adding the past participle of this verb.

\section{Margaret wrote the letter \\ The letter was written by Margaret}

The first example is an active sentence. To convert this active sentence to a passive sentence, you must first make the subject of the active sentence. Margaret, the object of the passive sentence with by. The object of the sentence, letter, becomes the subject of the passive sentence. Next, the passive verb can be formed. Because wrote is in the past tense in the active sentence, the past tense of be (was) is used in the passive 
sentence. Then the verb wrote in the active sentence is changed to the past participle written in the passive sentence.

It should be note that in a passive sentence, by + object does not used need to be included to have a complete sentence. The following are both examples of correct sentences.

The letter was written yesterday by Margaret.

The letter was written yesterday

Notice that these passive sentences are correct if by Margaret is include (as in the first example) or if by Margaret is omitted (as in the second example).

One way that the passive can be tested on the TOEFL test in simply with an incorrect form of the passive. The following are examples of passive errors that might appears on the TOEFL test.

The portrait was painting* by a famous artist.

The project will finished* by Tim.

In the first example, the passive is formed incorrectly because the past participle painted should be used rather than the present participle painting. In the second example, the verb be has not been included, and some form of the be is necessary from a passive verb. The verb in the second sentence should be will be finished.

When there is no object (with or without by) after a verb, you must look at the meaning of the sentence to determine if the verb should be active or passive. Sentences with an incorrect passive verb and no by + object to tell you that the verb should be passive are the most difficult passive errors to recognize on the TOEFL test. For examples:

We mailed the package at the post office.

The letter was mailed by us today before noon.

The letter was mailed today before noon.
The letter mailed* today before noon.

The first three examples above are correct. The first example has the active verb mailed used with the object package, the second example has the passive verb was mailed used with by us; the third sentence has the passive verb was mailed used without an object. The fourth example is the type of passive error that appears most often on the TOEFL test. This type of sentence has the following characteristics: (1) an incorrect passive verb that looks like a correct active verb, and (2) no $b y+$ object to tell you that a passive is needed. To correct the fourth example, the active verb needs to be change to the passive was mailed.

The determine that such a sentence is incorrect, you must study the meaning of the subject and the verb. You must ask yourself if the subject does the action of the verb (so an active verb is needed) or if the subject receives the action of the verb (so a passive verb is needed). In the incorrect example, you should study the meaning of the subject and verb, the letter mailed. You should ask yourself if a letter mails itself (the letter does the action) or if someone mails a letter (the letter receives the action of being mailed). Since letter does not mail itself, the passive is required in this sentence.

\section{h. Nouns}

The same type of problem with nouns appear often in the Written Expression of the TOEFL test. The participant should be familiar with these problems so that they will recognize them easily. They should be able to do the following: 
(1) Use the correct singular or plural noun.

A problem that is common in the Written Expression section of the TOEFL test is singular noun used where a plural noun is needed, or a plural noun used where a singular noun is needed. For examples: on the table, there were many dish. The lab assistance finished every tests. Based on the examples above, the incorrect form of noun is dish in singular form. It must be changed into plural form dishes because it follows the expression of quantity many. Tests must be changed into singular form (test) because it is followed by the expression of quantity every that must be followed by singular noun. In the Written Expression section of the TOEFL test, a test taker should watch very carefully the key words, such as each, every, a, one and single, that a noun should be singular. You should also watch carefully for such key words as many, several, both, various and two (or any other number except one) that indicate that noun should be plural.

(2) Distinguish countable and uncountable nouns.

In English, nouns are classified as countable or uncountable. For certain questions on the TOEFL test, it is necessary to distinguish countable and uncountable nouns in order to use the correct modifiers with them. As the name implies, countable nouns that can be counted. Countable nouns can come in quantities of one, or two, or a hundred, etc. The noun book is countable because you can have one book or several books.

Uncountable nouns, on the other hand, are nouns that cannot be counted because they come in some indeterminate quantity or mass. Nouns such as milk or happiness cannot be counted; you cannot have one milk or two milk, and you cannot find one happiness or two happiness. Uncountable nouns are often liquid item, such as water, oil, or shampoo. Uncountable nouns can also refer to abstract ideas, such as security, friendship, or hope. .It is important for a test taker to recognize the differences between countable and uncountable nouns when you come across such key words as much and many. For example: $\mathrm{He}$ has seen much foreign films. In this example, much is incorrect because films is countable noun, so the correct form is many. Another example, he didn't have many fun at the movies. Based on the example, many is not correct because it follows uncountable noun. While according to the rule, many is used for countable nouns.

(3) Recognize irregular singular and plural nouns.

Many nouns in English have irregular plurals and these irregular forms can cause confusion in the Written Expression section of the TOEFL test. The irregular forms that are the most problematic are plural forms that do not end in s. For example; the children is playing football. The incorrect form of the sentence is children is. Children is a plural form, so it must be followed by are. 
(4) distinguish the person form and the thing

Nouns in English can refer to person or things. Sometime in the written expression section or the TOEFL test the person is used in place of the thing, or the things used in place of the person. For example: There are many job opportunities in accountant*. In this sentence, accountant is the incorrect, because it refers to the person. While what the sentence needs refer to the thing " accounting".

\section{i. Pronouns}

Pronouns in the Written Expression of the TOEFL test are important to be checked the correct function in the sentence (as a subject or object, for example) and they agree with the noun they are replacing. The following pronoun problems are the most common on the TOEFL test : (1) distinguishing subject and object pronouns. (2) distinguishing possessive pronouns and possessive adjectives. (3). Checking pronoun reference for agreement. So, to answer the question of the Written Expression of the TOEFL test related to the pronouns correctly, the participants have to be able to solve the three pronoun problems by mastering them.

\section{j. Adjectives and adverbs}

Many different problems with adjectives and adverbs are possible in the Written Expression of the TOEFL test. To identify this problem, it is needed to able to recognize adjectives and adverbs There are three skills involving adjectives and adverbs that will help the participants on the Written Expression of the TOEFL test: (1) knowing when to use adjectives and adverbs. (2) using adjectives rather that adverbs after linking verbs. (3). Positioning adjectives and adverbs correctly.
There are still problems that are related only to adjectives. They are: -ly adjectives, predicate adjectives and -ed and -ing adjectives. The skills to handle this problem in answering the question of Written Expression of the TOEFL test are recognize -ly adjectives correctly and use -ed and -ing form correctly.

\section{k. Article}

Problems with articles in answering Written Expression of the TOEFL test can be handled by mastering the rules of the articles. The rules of the articles are: distinguishing a and an, making articles agree with nouns and distinguishing specific and general ideas. Nouns in English can be either countable or uncountable. If a noun is countable, it must be either singular or plural. In addition to these general type of nouns, there are two type of articles: definite (specific) and indefinite (general).

\section{l. Prepositions}

Preposition can be used in a literal way and an idiomatic way. In the literal one, the preposition means exactly what you expect. For example; the boy ran up the hill. The preposition up means the boy went to the direction up rather than down. Preposition in idiomatic way often appear in the Written Expression section of the TOEFL test. For example, $I$ called up my friends. The preposition up does not have the meaning which is related with the direction up but when the verb call followed up means telephone someone. There are two common types of problems with prepositions in the questions of the Written Expression of the TOEFL test. They are incorrect prepositions and omitted prepositions. To be able to answer the question correctly, it is important to recognize incorrect prepositions and when prepositions have been omitted. 


\section{m. Usage}

Phillips (2000 : 221) states that in English, certain groups of words have similar uses, and these words are sometimes confusing in the Written Expression of the TOEFL test. It is caused by some words which have similar meaning but they are different in use. The following problems are the most common: (1) when to use make and do. (2) When to use like, unlike and alike. (3) when to use other and another. So, it is important to master the rules of three problem.

\section{METHOD}

This is a quantitative research, intended to find out which categories of items in the Written Expression section of the TOEFL test were difficult for students. This research was conducted at the fourth semester students of English Study Program of UIN Suska Riau in Academic Year of 2018-2019. It was done for 3 months from May to July in 2018. The population of the study was all of the fourth semester students of English Study Program UIN Suska Riau. The researcher used a purposive sampling technique to take the sample. The researcher chose one class which consisted of 20 persons to be the sample of the research. The number of the students was 20 persons.

To know the students' difficulties in answering the written expression section of the TOEFL test, the researcher used a test form of TOEFL. The students were asked to identify the incorrect one or ungrammatical form of sentences by choosing one of the four underlined words or phrases. the items of the test were adapted from Longman Preparation Course for the TOEFL test book by Deborah Phillips, Cliffs TOEFL Preparation Guide by Michael at al and
Baron, how to prepare for the TOEFL by Sharpe. The number of items consisted of 40 items. Each item tested different categories of grammar. The categories of items were subject-verb agreement, parallel structure, comparative and superlative, the use of the verbs, passive verbs, nouns, pronouns, adjectives and adverbs, articles, prepositions and usages. The number of items of each category was different. It was arranged based on the problems that appear in answering each category of items in the Written Expression section of the TOEFL test as described above.

To measure the reliability and the validity of the test items, a try out was conducted

To analyze the difficulties faced by the students, the following formula was used.

$$
\mathrm{D}=\frac{E}{N \times I} \quad \text { (Hughes, 1989: 76) }
$$

When the average level of difficulty is higher than $40 \%$, the category is considered difficult. On the other hand, the average level of difficulty is smaller than $40 \%$, the category is considered easy.

\section{FINDINGS AND DISCUSSION}

The followings are the result of the test explaining the students' difficulties in answering the written expression section of the TOEFL test. The difficulties were classified into several categories which were determined based on the problems that always appear in answering the Written Expression section of the TOEFL Test. The categories were subject-verb agreements, parallel structures, comparatives and superlatives, the uses of the verbs, passive verbs, nouns, pronouns, adjectives and adverbs, articles, prepositions and usages. 
TABLE 4.1.

The Level of the Difficulties Faced by

the Students in answering the

Written Expression Section of the

TOEFL Test

\begin{tabular}{|l|l|l|l|}
\hline ID & \multicolumn{1}{|c|}{ Categories of Items } & $\begin{array}{c}\text { D } \\
\mathbf{( \% )}\end{array}$ & Remark \\
\hline 1 & Subject-Verb Agreements & 73.75 & Difficult \\
\hline 2 & Parallel Structures & 73.33 & Difficult \\
\hline 3 & $\begin{array}{l}\text { Comparatives and } \\
\text { Superlatives }\end{array}$ & 68.33 & Difficult \\
\hline 4 & The Forms of the Verb & 56.7 & Difficult \\
\hline 5 & The Uses of the Verb & 57.5 & Difficult \\
\hline 6 & Passive Verbs & 50 & Difficult \\
\hline 7 & Nouns & 77.5 & Difficult \\
\hline 8 & Pronouns & 70 & Difficult \\
\hline 9 & Adjectives and Adverbs & 74.2 & Difficult \\
\hline 10 & Articles & 73.3 & Difficult \\
\hline 11 & Prepositions & 65 & Difficult \\
\hline 12 & Usages & 81.7 & Difficult \\
\hline
\end{tabular}

Based on the table above, none of the categories of items were considered easy for the students in answering the Written Expression section of the TOEFL test; all of them were difficult for the students because they had level of difficulties bigger than $40 \%$.

\section{CONCLUSION}

Based on the result of the research, the researcher concludes that most of the fourth semester students of English Study Program of UIN Suska Riau got difficulties in answering the Written Expression section of the TOEFL test. All of the item categories of the Written Expression section of the TOEFL test were difficult for the students. The most difficult category of items for the students was usages, with the level of difficulty $81.7 \%$

In this research, the researcher suggests that:

1. The students have to pay attention to the categories of the Written Expression section of the TOEFL test in order to prepare themselves in the comprehensive exam on usage as one of the requirements to finish their study at S1 Degree in English Department.

2. Lecturers should teach the grammar subjects clearly that give them contribution in answering the Written Expression section of the TOEFL test.

3. Lecturers should explain the strategies of answering the Written Expression section of the TOEFL test as described by Deborah Phillip in her book " Longman Preparation Strategies for the TOEFL Test..

\section{REFERENCES}

Brown, Doughlas, H. 1993. Principles of Language Learning and Teaching. San Francisco State University: Englewood Cliffs

Heaton, J. B. 1975. Writing English Language Test. New York: Longman Inch.

Hornby, A. S. 1989. Oxford Advances Learners' Dictionary of Current English. London: Oxford University Press.

Hughes, A. 1989. Testing for Language Teachers. New York: Cambridge University Press.

Mary, Ellen and Michael, A. 1998. Cliffs TOEFL Preparation Guide. Nebraska: Lincoln.

Phillips, Deborah. 2000. Longman Preparation Course for the TOEFL Test. New York: Longman Inch.

Stanley, Nancy and King Carol. 1989. Building Skill for the TOEFL. Hong Kong : Nelson and Sons Ltd. Sharpe, Ph. D and Pamela, J. 2000. Barron. How to Prepare for the TOEFL. The Ohio States University: Binarupa Aksara. 